\title{
Simple, insensitive to environmental matrix interferences method of trace cadmium determination in natural water samples
}

\author{
Marzena Adamczyk ${ }^{1} \cdot$ Malgorzata Grabarczyk $^{1}$
}

Received: 7 January 2019 / Revised: 29 January 2019 / Accepted: 4 February 2019 /Published online: 21 February 2019

(C) The Author(s) 2019

\begin{abstract}
A simple, fast, and inexpensive anodic stripping voltammetric procedure for trace determination of cadmium in natural water samples containing high concentrations of surface-active substances was described. It was proved that interferences from the organic matrix such as surface-active substances could be removed by the addition of Amberlite XAD-7 resin to the analyzed sample prior to the voltammetric measurement. A renewable mercury film silver-based electrode $(\mathrm{Hg}(\mathrm{Ag}) \mathrm{FE})$ was used as the working electrode. The following optimum conditions were found: $0.1 \mathrm{~mol} \mathrm{~L}^{-1}$ acetic acid, accumulation potential of $-0.8 \mathrm{~V}$, and accumulation time of $30 \mathrm{~s}$. The linear range of $\mathrm{Cd}(\mathrm{II})$ was observed over the concentration range from $5 \times 10^{-8}$ mol $\mathrm{L}^{-1}$ to $6 \times 10^{-5} \mathrm{~mol} \mathrm{~L}^{-1}$, with a correlation coefficient equal to 0.997 . The detection limit of Cd(II) for preconcentration time of $30 \mathrm{~s}$ was $1.3 \times 10^{-8} \mathrm{~mol} \mathrm{~L}^{-1}$. The proposed procedure was successfully tested for the detection of cadmium in different non-pretreated and non-deaerated real water samples.
\end{abstract}

Keywords Cadmium(II) $\cdot$ Anodic stripping voltammetry $\cdot$ Environmental water samples $\cdot$ Organic matrix

\section{Introduction}

Cadmium is a naturally occurring element which is not very abundant in Earth's crust (its average concentration in pure form is between $0.15-0.20 \mathrm{ppm}$ ), but it is widely dispersed in a variety of compounds. Most cadmium salts are easily soluble and therefore migration of this element in the natural environment can take place. Moreover, cadmium forms soluble complexes with organic compounds, which increases its mobility. When introduced into the soil, cadmium is generally easily soluble especially in acidic conditions and can be leached out of soils much faster than other heavy metals. Despite its easy solubility, cadmium is not present in solutions of unpolluted soils. Regardless of the soil reaction, cadmium is very easily absorbed by plants [1].

Cadmium is regarded as an extremely toxic element and considered non-essential for living organisms. The high

Marzena Adamczyk

marzena.adamczyk@poczta.umcs.lublin.pl

1 Department of Analytical Chemistry and Instrumental Analysis, Chemical Faculty, Maria Curie-Sklodowska University, M. Curie-Sklodowskiej Sq. 3, 20-031 Lublin, Poland toxicity of this metal is the result of a long half-life and accumulation in soft tissues, mainly in the kidney and liver. Exposure to cadmium can cause severe damage to those organs. Cadmium has been proven to have a long resident time in the body making it a dangerous cumulative poison. An excess of this heavy metal causes many diseases such as anemia, osteoporosis, impaired odors, and proteinuria. Cadmium is also deposited in the placenta of mothers who smoke during pregnancy or are exposed to higher concentrations of this metal in other ways. It has the ability to change the function and structure of the bearing, disturbing fetal development. Furthermore, it was found out that permanent exposure to cadmium compounds of pregnant female rats caused severe defects in offspring, such as lack of eyes, hydrocephalus, cerebral hernia, or lack of metatarsal bones. Carcinogenic effects of cadmium were also found in rats [2-4].

Toxic effects show free cadmium ions that are present in substantial amounts particularly in environmental waters. Most of them are continuously added to the environment as a consequence of human activities that cause water pollution. Therefore, it is necessary to perform the determination of trace amounts of cadmium in environmental water samples [4].

To date, various methods for the determination of cadmium in environmental samples have been described. Among the available measurement techniques are located 
chemiluminescence (CL) [5], ion chromatography [6], atomic absorption spectrometry [7-9], spectrophotometry [10], fluorescence [11], resonance Rayleigh scattering method [12], ultraviolet spectrometry [11-14], cold vapor atomic absorption spectrometry (CV-AAS) [15], atomic fluorescence spectrometry (AFS) [16], and inductively coupled plasma mass spectrometry (ICP-MS) [13]. The majority of those analytical methods are associated with expensive apparatus, pretreatment of real samples, and complicated procedures. That is why voltammetric methods have been proposed and are considered to be preferable for the analysis of trace or ultra-trace heavy metals [17, 18], including cadmium [19-29]. Among voltammetric techniques, the anodic stripping voltammetry (ASV) and adsorptive stripping voltammetry (AdSV) have commonly been used for cadmium determination. Recently, a few ASV procedures have been reported for the determination of cadmium at various chemically modified electrodes. In these procedures, different electrodes were used such as the edge plane pyrolytic graphite [20], carbon nanotube nanoelectrode array [21], Nafion-coated bismuth film electrode [22], bismuth film zeolite doped carbon paste electrode [23], bismuth nano-powder electrode [24], carbon paste electrode modified with organofunctionalized mesoporous silica [25], bismuth/poly (bromocresol purple) film modified glassy carbon electrode [26], PAN-Nafion modified glassy carbon [27], carbon paste electrode modified with zirconium phosphate amorphous silica [28], and bismuth-antimony film electrode [29].

In the above-mentioned cases, the modification of the working electrode using a strictly defined chemical compound as a modifier improves the mechanical stability of the film. Moreover, these solutions significantly reduce the interference from foreign ions contained in the sample solution and in some cases they also improve resistance to various surfactants that may adsorb on the electrode surface from the solution. However, to eliminate the effect of adsorption, removal or destruction of organic matter is desirable prior to the stripping analysis of organic-rich samples. This is usually accomplished using ultraviolet irradiation or ozone oxidation procedures $[30,31]$. Both of which take a long time. Some analysts used silica for adsorptive stripping voltammetry in the presence of organic surfactants [32] and poly (ester-sulfonic acid)-coated mercury film electrodes for ASV [33]. Others used adsorption and chelate ion-exchange columns in a flow injection system to remove humic acid and surfactant interferences [34]. The use of potassium iodine to eliminate organic matrix in ASV is also known [35]. For samples low in dissolved organics, the standard additions method was used to correct the effect of organic interference [30-34].

It is well known that voltammetric techniques are generally prone to interference by organic constituents in the aqueous sample. Thereof, its avoidance or minimization in the sample is critical for the reliable determination of various elements in the sample. That is why insensitivity to the organic matrix is such an important parameter of determination procedures in natural samples. Multiple papers were devoted to the determination of cadmium by the ASV method. However, only in a few of them (mentioned in the previous paragraph) the elimination of interferences caused by organic compounds was addressed. So to fill the gap related to this issue, in the proposed work, we focused on eliminating interference in the presence of surfactants by using the adsorption nature of Amberlite XAD-7 resin. In the present article, a simple procedure for the determination of trace $\mathrm{Cd}(\mathrm{II})$ in natural water by anodic stripping voltammetry at a renewable mercury film silver-based electrode $(\mathrm{Hg}(\mathrm{Ag}) \mathrm{FE})$ was proposed. The procedure was applied to the determination of $\mathrm{Cd}(\mathrm{II})$ in natural water samples without any pretreatment with satisfactory results.

\section{Experimental}

\section{Apparatus}

The measurements were performed using a $\mu$ Autolab analyzer (Utrecht, The Netherlands). A three electrode system consisting of an $\mathrm{Hg}(\mathrm{Ag}) \mathrm{FE}$ working electrode, a Pt auxiliary electrode, and an $\mathrm{Ag} / \mathrm{AgCl}$ reference electrode (in saturated $\mathrm{NaCl}$ ) were used in all experiments. Pt electrode and an $\mathrm{Ag} / \mathrm{AgCl}$ electrode have been prepared in our laboratory. $\mathrm{Hg}(\mathrm{Ag})$ FE electrode was purchased from the MTM-ANKO Cracow, Poland.

The $\mathrm{Hg}(\mathrm{Ag})$ FE electrode is constructed in such a way that it is possible to refresh the mercury film before each measurement without the necessity of electrochemical purification. The refreshing of the mercury film occurs as a result of inserting a silver wire on which the mercury film is formed into the center of the electrode. During this stage, the silver wires crossed with especial O-rings and there was a precise wiping. Afterwards, the silver wire was ejected outside the electrode corpus through the mercury compartment and the mercury film was created [36, 37]. The $\mathrm{Hg}$ film area was $7 \mathrm{~mm}^{2}$.

\section{Reagents}

All solutions were prepared from triply distilled water. A working standard solution of $1 \times 10^{-4} \mathrm{~mol} \mathrm{~L}^{-1} \mathrm{Cd}$ (II) was prepared from a dilution of $1 \mathrm{~g} \mathrm{~L}^{-1} \mathrm{Cd}(\mathrm{II})$ standard solution (Merck) of the highest purity and $1 \mathrm{~mol} \mathrm{~L}^{-1} \mathrm{CH}_{3} \mathrm{COOH}$, $1 \mathrm{~mol} \mathrm{~L}^{-1} \mathrm{HNO}_{3}, 1 \mathrm{~mol} \mathrm{~L}{ }^{-1} \mathrm{HCl}, 1 \mathrm{~mol} \mathrm{~L}^{-1} \mathrm{H}_{2} \mathrm{SO}_{4}$, $1 \mathrm{~mol} \mathrm{~L}^{-1} \mathrm{H}_{3} \mathrm{PO}_{4}$, acetate buffer $(\mathrm{pH}=3.1)$, and acetate buffer $(\mathrm{pH}=3.6)$ as required. Triton X-100, cetyltrimethylammonium bromide (CTAB), and rhamnolipid were purchased prom Fluka (Buchs, Switzerland). Amberlite XAD-7 was obtained from Sigma, washed four times in triply distilled water, and dried up at the temperature of $50{ }^{\circ} \mathrm{C}$. 
Fig. 1 The influence of Triton $\mathrm{X}-100$ on the $\mathrm{Cd}(\mathrm{II})$ peak current. Without Amberlite XAD-7 resin (procedure B) (a). With Amberlite XAD-7 resin (procedure A) (b). Concentration of Cd(II) $1 \times$

$10^{-5} \mathrm{~mol} \mathrm{~L}^{-1}$, accumulation time $30 \mathrm{~s}$

Fig. 2 The influence of CTAB on the $\mathrm{Cd}(\mathrm{II})$ peak current. Without Amberlite XAD-7 resin (procedure B) (a). With Amberlite XAD-7 resin (procedure A) (b). Concentration of Cd(II) $1 \times$ $10^{-5} \mathrm{~mol} \mathrm{~L}^{-1}$, accumulation time $30 \mathrm{~s}$
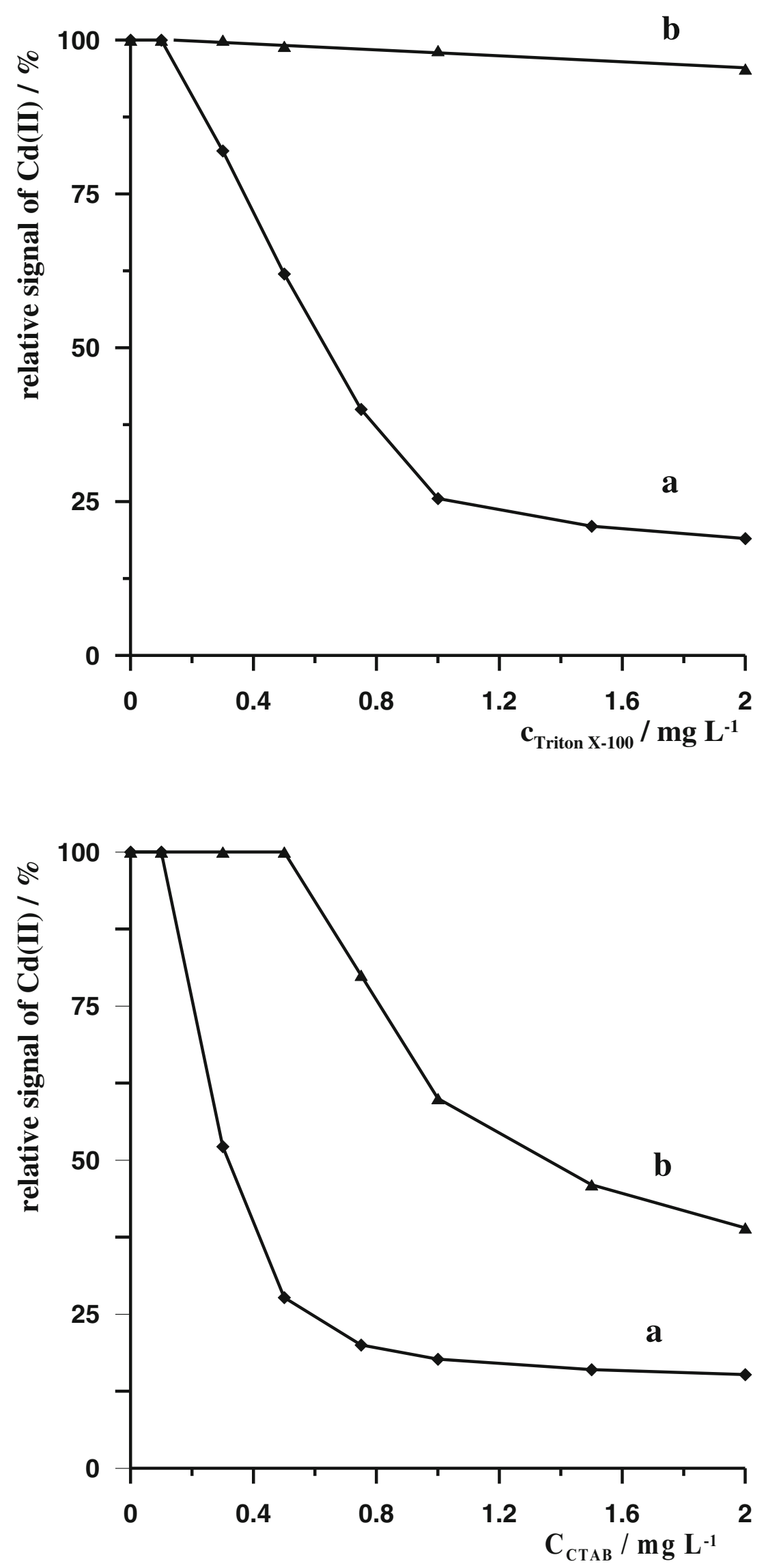
Fig. 3 The influence of rhamnolipid on the $\mathrm{Cd}(\mathrm{II})$ peak current. Without Amberlite XAD7 resin (procedure B) (a). With Amberlite XAD-7 resin (procedure A) (b). Concentration of Cd(II) $1 \times 10^{-5} \mathrm{~mol} \mathrm{~L}^{-1}$, accumulation time $30 \mathrm{~s}$

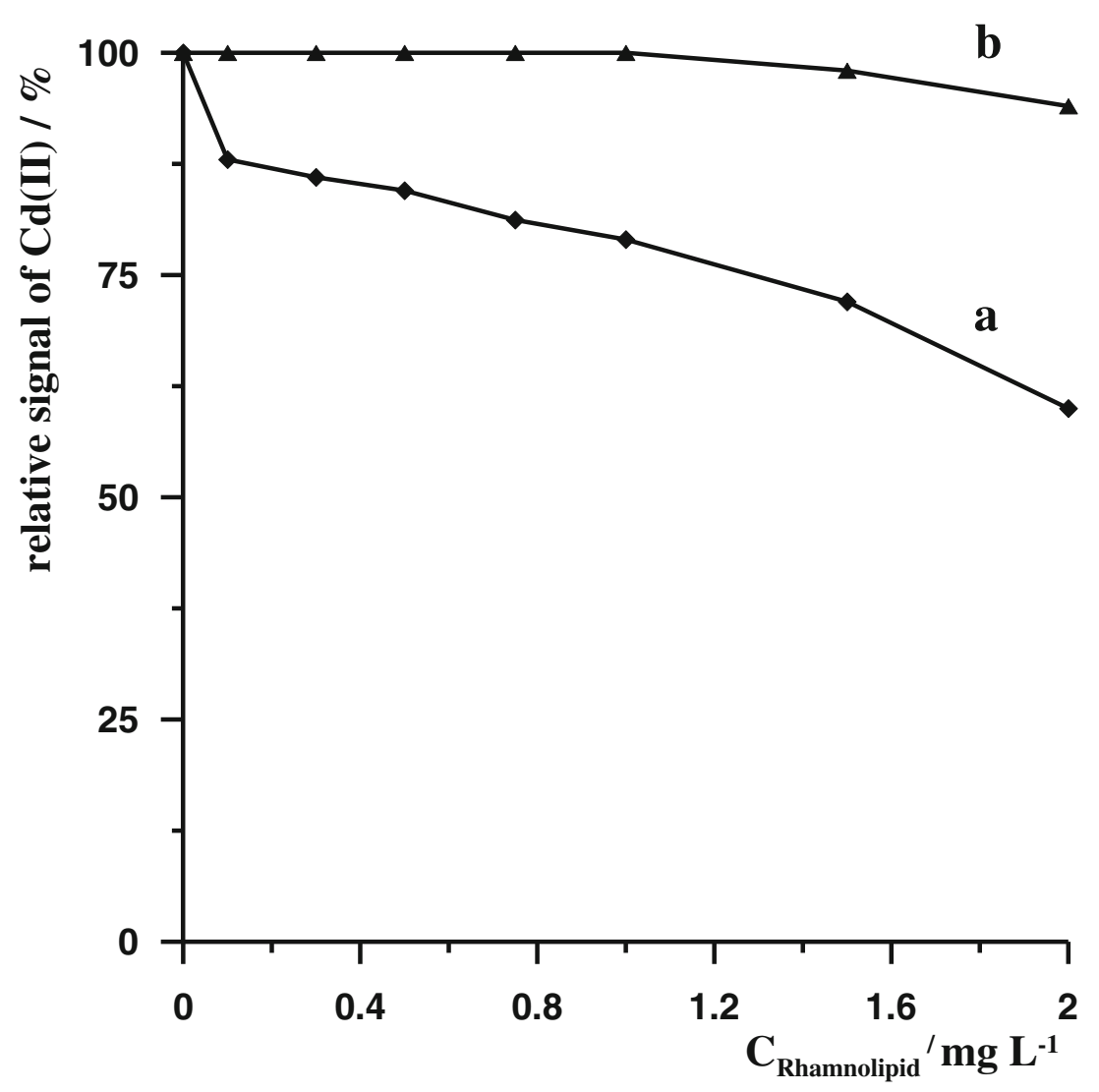

\section{Measurement procedure}

\section{Procedure $A$ (voltammetric procedure with elimination of organic interferents)}

For effective elimination of organic interferents, an analyzed real sample or a synthetic sample (containing $\mathrm{Cd}(\mathrm{II})$ and

Table 1 Concentrations of elements in certified reference material SPSWW1 Waste Water

\begin{tabular}{lc}
\hline Element & Concentration in $\mathrm{ng} / \mathrm{mL}\left(20{ }^{\circ} \mathrm{C}\right)$ \\
\hline $\mathrm{Al}$ & $2000 \pm 10$ \\
$\mathrm{As}$ & $100.0 \pm 0.5$ \\
$\mathrm{Cd}$ & $20.0 \pm 0.1$ \\
$\mathrm{Co}$ & $60.0 \pm 0.3$ \\
$\mathrm{Cr}$ & $200 \pm 1$ \\
$\mathrm{Cu}$ & $400 \pm 2$ \\
$\mathrm{Fe}$ & $1000 \pm 5$ \\
$\mathrm{Mn}$ & $400 \pm 2$ \\
$\mathrm{Ni}$ & $1000 \pm 5$ \\
$\mathrm{P}$ & $1000 \pm 5$ \\
$\mathrm{~Pb}$ & $100.0 \pm 0.5$ \\
$\mathrm{~V}$ & $100.0 \pm 0.5$ \\
$\mathrm{Zn}$ & $600 \pm 6$ \\
\hline
\end{tabular}

optionally organic interferents), $1.5 \mathrm{~mL}$ of $1 \mathrm{~mol} \mathrm{~L}^{-1}$ acetic acid, and an adequate volume of triply distilled water (so that the final volume of the solution was $15 \mathrm{~mL}$ ) were added to the electrochemical cell and finally $0.4 \mathrm{~g}$ of XAD-7 resin was inserted. The standard measuring procedure was performed using differential pulse anodic stripping voltammetry. Cadmium was stripped from the electrode surface at $-0.8 \mathrm{~V}$ for $30 \mathrm{~s}$ and after the equilibration time of $5 \mathrm{~s}$ a differential pulse voltammogram was recorded, while the potential was scanned from $-0.4 \mathrm{~V}$ to $-0.8 \mathrm{~V}$ with the intensity of the obtained peak directly proportional to the concentration of $\mathrm{Cd}$ (II) in the sample. The cadmium peak appeared at -

Table 2 Results of Cd(II) determination in certified reference material SPS-WW1 Waste Water

\begin{tabular}{lll} 
Sample & \multicolumn{2}{c}{ Cd(II) concentration $(\mathrm{ng} / \mathrm{mL})$} \\
\cline { 2 - 2 } & Proposed method & Reference value \\
\hline SPS-WW1 Waste Water & $19.7 \pm 0.5$ & $20.0 \pm 0.1$ \\
\hline * The primary reference materials used in the production have been traced \\
$\begin{array}{l}\text { to Standard Reference Materials issued by National Institute of Standards } \\
\text { and Technology (USA) by measurements applying inductively coupled } \\
\text { plasma atomic emission spectrometry (ICP-OES) } \\
\text { coupled plasma mass spectrometry (ICP-MS) }\end{array}$
\end{tabular}


Fig. 4 Differential pulse voltammograms obtained for different Cd(II) concentrations in the synthetic sample. Without addition of cadmium (a); $5 \times$ $10^{-8} \mathrm{~mol} \mathrm{~L}^{-1} \mathrm{Cd}(\mathrm{II})(\mathrm{b}) ; 1 \times$ $10^{-7} \mathrm{~mol} \mathrm{~L}^{-1} \mathrm{Cd}(\mathrm{II})(\mathrm{c}) ; 2 \times$ $10^{-7} \mathrm{~mol} \mathrm{~L}^{-1} \mathrm{Cd}(\mathrm{II})(\mathrm{d}) ; 3 \times$ $10^{-7} \mathrm{~mol} \mathrm{~L}^{-1} \mathrm{Cd}(\mathrm{II})(\mathrm{e}) ; 4 \times$ $10^{-7} \mathrm{~mol} \mathrm{~L}^{-1} \mathrm{Cd}(\mathrm{II})(\mathrm{f})$.

Concentration of acetic acid $0.1 \mathrm{~mol} \mathrm{~L}^{-1}$. Accumulation potential $-0.8 \mathrm{~V}$ and accumulation time $30 \mathrm{~s}$

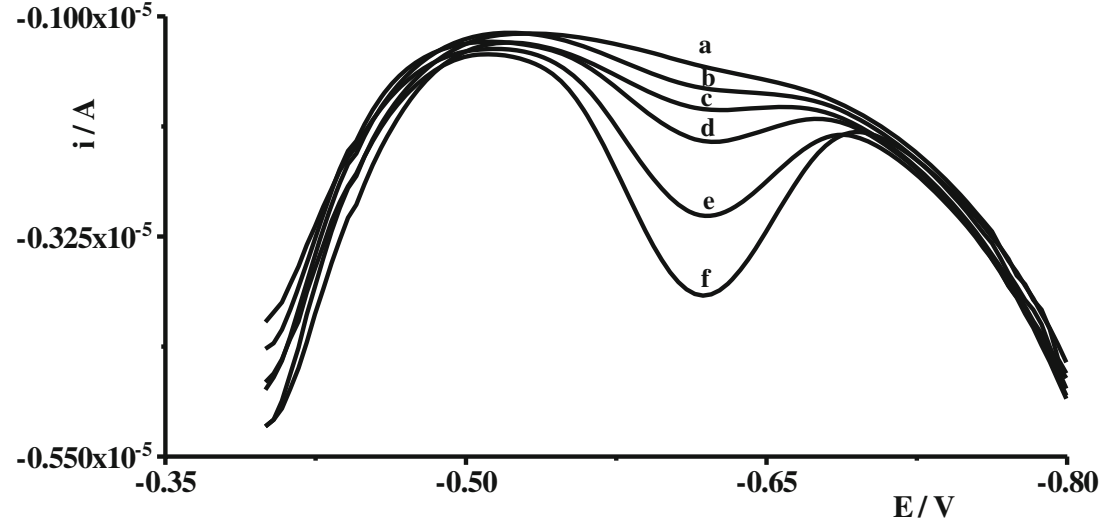

$0.6 \mathrm{~V}$. The scan rate, pulse time, and pulse height were 20 $\mathrm{mVs}^{-1}, 2 \mathrm{~ms}$ and $50 \mathrm{mV}$, respectively.

\section{Procedure $B$ (voltammetric procedure without elimination of organic interferents)}

The analyzed real or synthetic sample (as described above) was transferred directly to the electrochemical cell and $1.5 \mathrm{~mL}$ of $1 \mathrm{~mol} \mathrm{~L}^{-1}$ acetic acid was added and finally water was added to $15 \mathrm{~mL}$. Then a voltammetric measurement was performed as described above.

\section{Results and discussion}

\section{Choice of supporting electrolyte}

The measurements were performed using procedure $B$ for solutions containing a constant concentration of $\mathrm{Cd}(\mathrm{II})$ equal to $1 \times 10^{-5} \mathrm{~mol} \mathrm{~L}^{-1}$ and the following supporting electrolyte with a concentration of $0.1 \mathrm{~mol} \mathrm{~L}^{-1} \mathrm{HNO}_{3}, \mathrm{H}_{2} \mathrm{SO}_{4}, \mathrm{H}_{3} \mathrm{PO}_{4}$, $\mathrm{HCl}, \mathrm{CH}_{3} \mathrm{COOH}$, and acetate buffer $\mathrm{pH}$ equal to 3.1 or 3.6. It was observed that of all the examined supporting electrolytes an extreme signal was obtained in $\mathrm{CH}_{3} \mathrm{COOH}$ so this acid was chosen for further research.

Fig. 5 Differential pulse voltammograms obtained during $\mathrm{Cd}(\mathrm{II})$ determination in the Krezniczanka river water. Diluted tenfold (a); as (a) $+2,5 \times$ $10^{-7} \mathrm{~mol} \mathrm{~L}^{-1} \mathrm{Cd}(\mathrm{II})(\mathrm{b})$; as (a) + $1 \times 10^{-6} \mathrm{~mol} \mathrm{~L}^{-1} \mathrm{Cd}(\mathrm{II})(\mathrm{c})$; as (a) $+2 \times 10^{-6} \mathrm{~mol} \mathrm{~L}^{-1} \mathrm{Cd}$ (II) (d). Concentration of acetic acid $0.1 \mathrm{~mol} \mathrm{~L}^{-1}$. Accumulation potential $-0.8 \mathrm{~V}$ and accumulation time $30 \mathrm{~s}$. Procedure A with $0.4 \mathrm{~g}$ Amberlite XAD-7 resin

\section{Effect of accumulation potential and time}

The influence of the accumulation potential on the peak current was examined using procedure $B$ in the potential range from -1.2 to $-0.6 \mathrm{~V}$, using a solution containing $1 \times$ $10^{-5} \mathrm{~mol} \mathrm{~L}^{-1}$ of $\mathrm{Cd}(\mathrm{II})$ and $0.1 \mathrm{~mol} \mathrm{~L}^{-1}$ of $\mathrm{CH}_{3} \mathrm{COOH}$. The peak current increased with the changing potential from -1.2 to $-0.8 \mathrm{~V}$ and then in the range from -0.7 to $-0.6 \mathrm{~V}$ the peak current slightly decreased. On the basis of these results, the accumulation potential of $-0.8 \mathrm{~V}$ at which a maximum peak was obtained was selected for further research.

The effect of preconcentration time on the voltammetric response of cadmium in the range from 10 to $60 \mathrm{~s}$ was also studied. The peak current increased upon increasing the accumulation time to $30 \mathrm{~s}$ and then it was constant. So the accumulation time equal to $30 \mathrm{~s}$ was chosen for further investigations.

\section{Conditions of differential pulse voltammetry}

For determination of $\mathrm{Cd}$ (II) ions using differential pulse voltammetry, optimization of the following instrumental parameters was performed: pulse time and pulse height. The influence of pulse time was examined in the range of 2 to $20 \mathrm{~ms}$, and it occurred that with the increase of pulse time the peak of cadmium decreased, so the time equal to $2 \mathrm{~ms}$ was chosen.

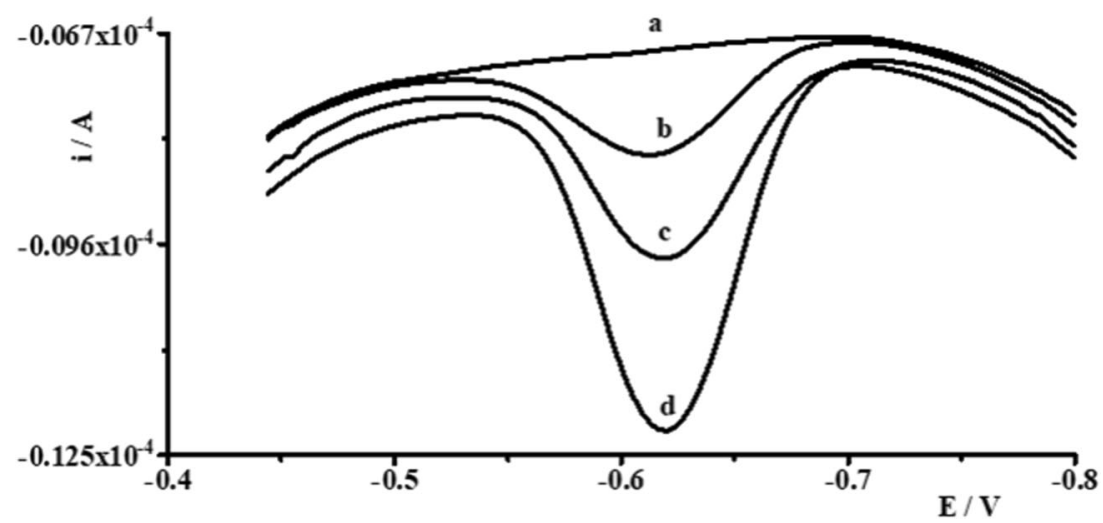


Variation of the pulse height between 20 and $100 \mathrm{mV}$ showed that with the increase of pulse height, the peak current of cadmium increased too; however, at higher values, the shape of the peak became worse. As the compromise, the amplitude of $50 \mathrm{mV}$ was practiced.

\section{The calibration graph}

The calibration graph for $\mathrm{Cd}(\mathrm{II})$ was linear in the range from $5 \times 10^{-8}$ to $6 \times 10^{-5} \mathrm{~mol} \mathrm{~L}^{-1}$ for an accumulation time of $30 \mathrm{~s}$ and obeyed the equation $y=1.644 \mathrm{x}+0.932$, where $y$ and $x$ are the peak current $(\mu \mathrm{A})$ and $\mathrm{Cd}(\mathrm{II})$ concentration $\left(\mu \mathrm{mol} \mathrm{L} \mathrm{L}^{-1}\right)$, respectively. The linear correlation coefficient was $r=0.997$. The relative standard deviation (RSD) from five determinations of $\mathrm{Cd}(\mathrm{II})$ at a concentration of $2 \times 10^{-7} \mathrm{~mol} \mathrm{~L}^{-1}$ was $3.3 \%$. The detection limit estimated from three times the standard deviation for the lowest studied Cd(II) concentration and accumulation time of $30 \mathrm{~s}$ was about $1.3 \times 10^{-8} \mathrm{~mol} \mathrm{~L}^{-1}$.

\section{Interference of organic compounds}

In the proposed work, special attention was devoted to a precise study of the influence of surface-active substances on the cadmium voltammetric signal. Triton X-100, cetyltrimethylammonium bromide (CTAB), and Rhamnolipid, as the representative for non-ionic surfactant, cationic surfactants, and biosurfactant, respectively, were chosen to test. The measurements were performed using procedure $A$ and procedure $B$ for each surfactant separately. In procedure $A$, interferences connected with the presence of surface-active substances were reduced using Amberlite XAD-7 resin. Figures 1, 2, and 3 present the influence of Triton X-100, CTAB, and Rhamnolipid, respectively, on the voltammetric signal of cadmium obtained using procedure $A$ (with elimination of interferences) - curve b, and for comparison using procedure $B$ (without elimination of interferences) - curve a. Based on literature data reporting that natural waters contain surfactants with the surface active effect similar to the effect induced by 0.2 to $2 \mathrm{ppm}$ of Triton X-100 [38], we conducted our research using such concentrations of the examined surfactants.

As can be seen in Fig. 1 (curve a), Triton X-100 concentration of $2 \mathrm{mg} \mathrm{L}^{-1}$ decreases the Cd(II) signal by $80 \%$. However, in the presence of the Amberlite XAD-7 resin (curve b), no effect of Triton X-100 on the Cd(II) peak current is observed at the same concentration. In Fig. 2, it can be observed that $0.5 \mathrm{mg} \mathrm{L}^{-1}$ of CTAB causes the reduction of the Cd(II) signal by $75 \%$ without using a resin (curve a), whereas in the presence of the resin, the same concentration of CTAB does not disturb the peak current of cadmium (curve b). In the case of Rhamnolipid (Fig. 3), its concentration of $2 \mathrm{mg} \mathrm{L}^{-1}$ causes a decrease of the voltammetric signal of cadmium to $60 \%$ of its original value (curve a), while using the addition of a resin, the effect of the same concentration of this surfactant is insignificant.

\section{Validation and analytical applications}

The proposed method has been validated through Cd(II) determination in the certified reference material SPS-WW1 Waste Water (batch 111). This material contains besides cadmium other trace elements such as $\mathrm{Al}, \mathrm{As}, \mathrm{Co}, \mathrm{Cr}, \mathrm{Cu}, \mathrm{Fe}, \mathrm{Mn}$, $\mathrm{Ni}, \mathrm{P}, \mathrm{Pb}, \mathrm{V}$, and $\mathrm{Zn}$. Concentrations of all elements in the certified reference material SPS-WW1 Waste Water are presented in Table 1.

The analyses were performed with the standard addition method. The waste water was added directly to the voltammetric cell without any pretreatment. In the first step of the standard addition method, the test solution was prepared by tenfold dilution of certified reference material in distilled water and next the voltammogram was recorded. Subsequently, further portions of the known amount of cadmium were added to the test solution. Voltammograms were recorded after each addition of cadmium. The results of Cd(II) determination in certified reference material are presented in Table 2.

In order to demonstrate the applicability and reliability of the presented procedure, recovery tests were carried out by taking two different fresh natural water samples and by adding known quantities of $\mathrm{Cd}(\mathrm{II})$ standard to each sample. The analyzed samples were spiked with $\mathrm{Cd}(\mathrm{II})$ so that the cadmium content was below the detection limit of the proposed method. The analyzed samples were collected from eastern areas of Poland, river water (the Krezniczanka river), and stagnant water (Lake Zemborzyce) and were submitted to analysis without any pretreatment. Three replicate determinations using the standard addition method gave the average recovery values between 98.4 and $103.1 \%$ for $\mathrm{Cd}(\mathrm{II})$ in the Krezniczanka river sample with relative standard deviation between 3.3 and $3.7 \%$ and 97.4 and $99.8 \%$ for Cd(II) in the sample from Lake Zemborzyce with relative standard deviation between 3.5 and $4.2 \%$. The typical voltammograms obtained in the course of the Krezniczanka river analysis are presented in Figs. 4 and 5.

\section{Conclusions}

The application of Amberlite XAD-7 resin made it possible to elaborate a simple and fast voltammetric procedure in which interferences from surface-active compounds were minimalized. Its main advantage is the possibility of cheap direct determination of $\mathrm{Cd}(\mathrm{II})$ in natural samples containing surfactants without the necessity of preliminary UVirradiation of the samples, which drastically reduces analysis time. To prove the practical applicability, the proposed 
procedure was successfully applied to the quantification of cadmium in environmental water samples. The abovedescribed procedure looks promising and can be recommended for monitoring the environment, which is necessary to evaluate the soil-plant system.

Open Access This article is distributed under the terms of the Creative Commons Attribution 4.0 International License (http:// creativecommons.org/licenses/by/4.0/), which permits unrestricted use, distribution, and reproduction in any medium, provided you give appropriate credit to the original author(s) and the source, provide a link to the Creative Commons license, and indicate if changes were made.

Publisher's note Springer Nature remains neutral with regard to jurisdictional claims in published maps and institutional affiliations.

\section{References}

1. Merian E, Anke M, Ihnat M, Stoeppler M (2004) Elements and their compounds in the environment: occurrence, analysis and biological relevance. No. Ed. 2:323-325

2. Ensafi AA, Khayamian T, Benvidi A, Mirmomtaz E (2006) Simultaneous determination of copper, lead and cadmium by cathodic adsorptive stripping voltammetry using artificial neural network. Anal Chim Acta 561:225-232

3. Waalkes MP (2000) Cadmium carcinogenesis in review. J Inorg Biochem 79:241-244

4. Mena C, Cabrera C, Lorenzo ML, López MC (1996) Cadmium levels in wine, beer and other alcoholic beverages: possible sources of contamination. Sci Total Environ 181:201-208

5. Taverna PJ, Mayfield H, Andrews ARJ (1998) Determination of cadmium ions in water by a novel electrochemiluminescence method. Anal Chim Acta 373:111-117

6. Paull B, Twohill E, Bashir W (2000) Determination of trace cadmium in environmental water samples using ion-interaction reversed-phase liquid chromatography with fluorescence detection. J Chromatogr A 877:123-132

7. Dadfarnia S, Shabani AHM, Kamranzadeh E (2009) Separation/ preconcentration and determination of cadmium ions by solidification of floating organic drop microextraction and FI-AAS. Talanta 79:1060-1065

8. Santos WNLD, Costa JLO, Araujo RGO, Jesus DSD, Costa ACS (2006) An on-line pre-concentration system for determination of cadmium in drinking water using FAAS. J Hazard Mater 137: 1357-1361

9. Pourreza N, Mousavi HZ (2004) Determination of cadmium by flame atomic absorption spectrometry after preconcentration on naphthalene-methyltrioctylammonium chloride adsorbent as tetraiodocadmate (II) ions. Anal Chim Acta 503:279-284

10. Li Z, Tang J, Pan J (2006) Determination of cadmium in tableware leach solution by spectrophotometry using 2,6dimethylphenyldiazoaminobenzene. Food Control 17:551-556

11. Liu JN, Zhang B, Wu BW, Liu YC, Yu XQ (2006) Spectrofluorimetric determination of trace amounts of cadmium with 2,4-dihydroxyacetophenone benzoylhydrazone. Rare Metals 25:184-189

12. Liu SP, Liu ZF, Luo HQ (2000) Resonance Rayleigh scattering method for the determination of trace amounts of cadmium with iodide-rhodamine dye systems. Anal Chim Acta 407:255-260
13. Li L, Hu B, Xia L, Jiang Z (2006) Determination of trace Cd and Pb in environmental and biological samples by ETV-ICP-MS after single-drop microextraction. Talanta 70:468-473

14. Melchior A, Peressini S, Portanova R, Sangregorio C, Tavagnacco C, Tolazzi M (2004) Cobalt (II) and cadmium(II) chelates with nitrogen donors and O-2 bonding to $\mathrm{Co}$ (II) derivatives. Inorg Chim 357:3473-3482

15. Manzoori JL, Abdolmohammad-Zadeh H, Amjadi M (2007) Ultratrace determination of cadmium by cold vapor atomic absorption spectrometry after preconcentration with a simplified cloud point extraction methodology. Talanta 71:582-587

16. Duan T, Song X, Jin D, Li H, Xua J, Chen H (2005) Preliminary results on the determination of ultratrace amounts of cadmium in tea samples using a flow injection on-line solid phase extraction separation and preconcentration technique to couple with a sequential injection hydride generation atomic fluorescence spectrometry. Talanta 67:968-974

17. Culková E, Švorc L', Tomčík P, Durdiak J, Rievaj M, Bustin D, Brescher R, Lokaj J (2013) Boron-doped diamond electrode as sensitive and selective green electroanalytical tool for heavy metals environmental monitoring: zinc detection in rubber industry waste. Pol J Environ Stud 22:1317-1323

18. Chomisteková Z, Sochr J, Svítková J, Svorc L' (2011) Boron-doped diamond as the new electrode material for the determination of heavy metals. Acta Chim Slov 4:11-17

19. Mamani MCV, Aleixo LM, Abreu MF, Rath S (2005) Simultaneous determination of cadmium and lead in medicinal plants by anodic stripping voltammetry. J Pharm Biomed Anal 37:709-713

20. Kachoosangi RT, Banks CE, Ji X, Compton RG (2007) Electroanalytical determination of cadmium(II) and lead (II) using an in-situ bismuth film modified edge plane pyrolytic graphite electrode. Anal Sci 23:283-289

21. Liu G, Lin Y, Tub Y, Ren Z (2005) Ultrasensitive voltammetric detection of trace heavy metal ions using carbon nanotube nanoelectrode array. Analyst 130:1098-1101

22. Kefala G, Economou A, Voulgaropoulos A (2004) A study of Nafion-coated bismuth-film electrodes for the determination of trace metals by anodic stripping voltammetry. Analyst 129:10821088

23. Cao L, Jia J, Wang Z (2008) Sensitive determination of Cd and Pb by differential pulse stripping voltammetry with in situ bismuthmodified zeolite doped carbon paste electrodes. Electrochim Acta 53:2177-2182

24. Lee GJ, Lee HM, Rhee CK (2007) Bismuth nano-powder electrode for trace analysis of heavy metals using adodic striping voltammetry. Electrochem Commun 9:2514-2518

25. Popa DE, Buleandra M, Mureseanu M, Ionika MI, Tanase G (2010) Carbon paste electrode modified with organofunctionalized mesoporous silica for electrochemical detection and quantitative determination of cadmium (II) using square wave anodic stripping voltammetry. Rev Chim 61:162-167

26. Yang G, Yan J, Qi F, Sun C (2010) High sensitivity and reproducibility of a bismuth/poly (bromocresol purple) film modified glassy carbon electrode for determination of trace amount of cadmium by differential pulse anodic stripping voltammetry. Electroanalysis 22: 2729-2738

27. Phaisansuthichol S, Ratana-ohpas R, Dejmanee S (2012) Cadmium determination in phosphate fertiliser using a PAN-Nafion ${ }^{\circledR}$ modified glassy carbon electrode by stripping voltammetry. Int J Environ Anal Chem 92:783-796

28. Shams E, Torabi R (2006) Determination of nanomolar concentrations of cadmium by anodic-stripping voltammetry at a carbon paste electrode modified with zirconium phosphated amorphous silica. Sensors Actuators B 117:86-92

29. Yi WJ, Li Y, Ran G, Luo HQ, Li NB (2012) Determination of cadmium(II) by square wave anodic stripping voltammetry using 
bismuth-antimony film electrode. Sensors Actuators B 166-167: $544-548$

30. Batley GE, Farrar YJ (1978) Irradiation techniques for the release of bound heavy metals in natural waters and blood. Anal Chim Acta 99:283-292

31. Clem RG, Hodgson AT (1978) Ozone oxidation of organic sequestering agents in water prior to the determination of trace metals by anodic stripping voltammetry. Anal Chem 50:102-110

32. Kubiak W, Wang J (1989) Use of silica for adsorptive stripping voltammetry in the presence of organic surfactants. Electroanal Chem 258:41-48

33. Wang J, Taha Z (1990) Poly (ester sulfonic acid) coated mercury film electrodes for anodic stripping voltammetry. Electroanalysis 2: 383-387

34. Yang X, Risinger L, Johansson G (1987) Deoxygenation of supporting electrolytes in stripping voltammetry by glocuse and co-immobilized glocuse oxidase and catalase in a flow system. Anal Chim Acta 192:313-318

35. Feng Y, Barratt RS (1994) Effect of potassium iodide on reducing the adsorptive interference of surfactants and organics in the determination of lead and cadmium in environmental samples by differential-pulse anodic stripping voltammetry. Analyst 119: 2805-2808

36. Grabarczyk M, Wasag J (2016) Ultratrace determination of indium in natural water by adsorptive stripping voltammetry in the presence of cupferron as a complexing agent. J Electrochem Soc 163:H218 $\mathrm{H} 222$

37. Bas B, Kowalski Z (2002) Preparation of silver surface for mercury film electrode of prolonged analytical application. Electroanalysis 14:1067-1071

38. Cosovic B, Vojvodic V (1982) The application of ac polarography to the determination of surface-active substances in seawater. Limnol Oceanogr 27:361-369 